ADVANCED THERMALLY

ASSISTED SURFACE ENGINEERING PROCESSES 


\section{ADVANCED THERMALLY ASSISTED SURFACE ENGINEERING PROCESSES}

by

Ramnarayan Chattopadhyay

Mumbai , India

KLUWER ACADEMIC PUBLISHERS

NEW YORK, BOSTON, DORDRECHT, LONDON, MOSCOW 
eBook ISBN: $\quad 1-4020-7764-5$

Print ISBN: $\quad$ 1-4020-7696-7

(C2004 Kluwer Academic Publishers

New York, Boston, Dordrecht, London, Moscow

Print @2004 Kluwer Academic Publishers

Dordrecht

All rights reserved

No part of this eBook may be reproduced or transmitted in any form or by any means, electronic, mechanical, recording, or otherwise, without written consent from the Publisher

Created in the United States of America

Visit Kluwer Online at:

and Kluwer's eBookstore at: http://kluweronline.com

http://ebooks.kluweronline.com 


\section{DEDICATION}

To my father

\section{Jatindra Mohan Chatterjee}

Guiding spirit in the pursuit of intellectual excellence 


\section{Contents}

Preface $\quad$ xiii

Acknowledgements $\quad$ XV

\section{CHAPTER 1}

WEAR, SURFACE, HEAT AND SURFACE ENGINEERING 1

1.1 Wear 2

$\begin{array}{lll}1.2 & \text { Corrosion } & 6\end{array}$

$\begin{array}{lll}1.3 & \text { Surface Properties and Wear } & 16\end{array}$

1.4 Heat Energy \& Thermal Processes 23

1.4.1 Phase Rule \& Phase Transformations 27

1.4.2 Surface Property Modification \& Thermal Processes 33

$\begin{array}{ll}\text { 1.4.3 Heat Sources } & 34\end{array}$

$\begin{array}{ll}\text { References } & 46\end{array}$

\section{CHAPTER 2}

PLASMA ASSISTED THERMAL PROCESSES 49

2.1 Formation \& Properties of Plasma 49

2.2 Non-Transferred Arc Plasma Spraying 52

2.2.1 DC Arc Plasma Spray System $\quad 52$

2.2.2 Non-Transferred Arc Plasma Scan Hardening 77

$\begin{array}{lll}\text { 2.2.3 Post Spraying Processes } & 78\end{array}$

$\begin{array}{lll}2.3 & \text { Plasma Transferred Arc Processes } & 78\end{array}$

2.3.1 Transferred Arc-Plasma Surface Treatment by Scanning 90

$\begin{array}{lll}2.4 & \text { Plasma Nitriding } & 90\end{array}$

2.5 Plasma Carburizing 95

2.6 Plasma Paste Boronizing 96

2.7 Plasma Assisted Vapor Phase Deposition 97

2.7.1 Plasma Assisted PVD 97

$\begin{array}{ll}\text { 2.7.2 Plasma Assisted CVD (PCVD) } & 101\end{array}$

2.7.3 Vapor Phase Deposition Techniques of Diamond 103

2.8 Vapor Phase Deposition of Amorphous Materials 105

2.9 Plasma Assisted Polymer Surface Modification 106

$\begin{array}{ll}\text { References } & 112\end{array}$ 
viii

\section{CHAPTER 3}

ION BEAM PROCESSES 117

3.1 Ion Source 117

3.2 Ion Beam Assisted Vapor Deposition Processes 118

3.2.1 Types of Coating 120

3.2.2 Dual IBAD 124

3.3 Ion Implantation $\quad 125$

3.3.1 Plasma Source Ion Implantation 130

3.3.2 Reactive Ion Sputtered Coating $\quad 130$

3.4 Ion Beam Assisted EBPVD 132

References 132

\section{CHAPTER 4}

ELECTRON BEAM PROCESSES

4.1 Electron Beam 135

4.2 Electron Beam Assisted Physical Vapor Deposition 136

4.3 Electron Beam Welding 145

References 146

\section{CHAPTER 5}

MICROWAVE ASSISTED SURFACE MODIFICATION PROCESSES 149

5.1 Formation \& Properties of Microwave 149

5.2 Microwave Assisted Plasma CVD Process 152

5.3 Microwave Assisted Surface Diffusion 154

5.4 Microwave Sintering 155

5.5 Fused Ceramic Surfacing by Microwave 155

References 155

\section{CHAPTER 6}

LASER ASSISTED SURFACE ENGINEERING PROCESSES 157

6.1 Formation \& Properties of Laser 157

6.1.1 Lasing Elements 158

6.1.2 Pumping Systems 158

6.1.3 Techniques for Laser Formation $\quad 159$

6.1.4 Laser Focusing 164

6.1.5 Variables Affecting the Laser Assisted Processes 165

6.2 Laser Assisted Surface Modification Processes 167

$\begin{array}{ll}\text { Lasershot Peening } & 168\end{array}$

Transformation Hardening $\quad 169$

Laser Melting $\quad 170$

Laser Surface Alloying $\quad 175$

Laser Ablation $\quad 176$

Laser Fusion of Thermal Sprayed Deposit 177

$\begin{array}{ll}\text { Laser Assisted Vapor Deposition } & 178\end{array}$ 
Laser Welding $\quad 179$

Laser Spraying 186

Direct Metal Deposition (DMD) by Laser 188

References

\section{CHAPTER 7}

SOLAR ENERGY FOR SURFACE MODIFICATIONS 193

7.1 Solar Heating 193

7.1.1 Solar Furnace 193

$\begin{array}{ll}\text { 7.2 Solar Hardening } & 197\end{array}$

$\begin{array}{lll}7.3 & \text { Sunbeam Fusing } & 197\end{array}$

References 199

\section{CHAPTER 8}

COMBUSTION PROCESSES FOR SURFACE MODIFICATION 201

8.1 Heat \& Flame Generated by Oxy-Fuel Combustion Processes 201

8.1.1 Surface Modification Processes by Furnace Atmosphere

Control

8.2 Normal to Moderate Capacity Flame Spray/Fusion

Systems 204

8.2.1 High Velocity Flame Spraying 207

8.2.2 Hyper Velocity Impact Fusion (HVIF) 212

8.3 Hot Chemical Gas Flame for Diamond Film Deposition 213

8.4 Flame Assisted Vapor Deposition (FAVD) Process 215

References $\quad 216$

\section{CHAPTER 9}

FRICTION WELD SURFACING 219

9.1 Principles of Friction \& Frictional Heat 219

9.2 Friction Surfacing 222

References 226

\section{CHAPTER 10}

INDUCTION SURFACE MODIFICATION PROCESSES 229

10.1 Induction Heating of the Surface 229

10.2 Induction Hardening 230

10.2.1 Induction Hardening of Cast Iron Surface 233

10.3 Induction Fusing 233

10.4 Induction Coupled RF Plasma 236

References 237

\section{CHAPTER 11}

SURFACING BY SPARK DEPOSITION PROCESSES 239

11.1 Capacitance Discharge or Spark Deposition Process 239 


\section{CHAPTER 12}

ARC ASSISTED ADVANCED SURFACE ENGINEERING PROCESSES

12.1 Arc Phenomena in Welding \& Developments 243

12.1.1 Gas Tungsten Arc Welding 246

12.1.2 Gas Metal Arc Welding 247

12.1.3 Plasma Arc Welding with Rod/Wire 251

12.1.4 Submerged Arc Welding (SAW) Process 254

12.1.5 Electroslag Welding 258

12.2 Arc Light Assisted Processes 259

12.3 Advanced Arc Spraying Process 261

12.4 Electroconsolidation Cladding 263

References 264

\section{CHAPTER 13}

HOT ISOSTATIC PRESS 267

13.1 HIP Process 267

13.2 Diffusion Bonding by HIP 268

13.3 Hip Quenching of Diffused Layer 270

References $\quad 270$

\section{CHAPTER 14}

FLUID BED PROCESSES 271

14.1 Fluid Bed Processes for Thermal Treatments 271

14.2 Fluidised Gas Bed 272

14.2.1 Fluidised Gas Bed Carburizing 272

14.3 Thermal Processing in Molten Salt Bath 273

References $\quad 274$

CHAPTER 15

POLYMERIC SURFACES 275

15.1 Thermally Assisted Surface Modification of Polymeric Materials 275

15.2 Polymer Coatings on Metallic Substrate 276

15.3 Parylene Coatings 277

References 278

CHAPTER 16

CERAMIC SURFACES $\quad 279$

16.1 Ceramic Surface Modifications 279

16.2 Ceramic Coatings Materials/Processes 281

16.2.1 Ceramic Oxides 282 
16.2.2 Ceramic Carbides, Nitrides and Composites 282

References

\section{CHAPTER 17}

DIFFUSED AND CVD COATINGS OF SINGLE AND

MULTIPLE ELEMENTS

285

17.1 Diffusion Process 285

17.2 Diffusion Coatings of Interstitials 288

17.3 Diffusion Coating of Substitutional Elements 292

17.3.1 Pack Alunising 293

17.3.2 Pack Chromising 296

17.3.3 Siliconizing or Ihregizing 297

17.3.4 Chemical Vapor Deposition of Multilayer Coating 299

$\begin{array}{ll}17.4 \text { Diffusion Sinter Cladding } & 302\end{array}$

References 303

CHAPTER 18

MISCELLANEOUS PROCESSES 307

18.1 Fused Paste Coating 307

18.2 Wear Plates 308

18.3 Hard Top Casting 309

18.4 High Density Infrared Processing of Surface Layer 310

References $\quad 310$

CHAPTER 19

QUALITY OF THE ENGINEERED SURFACES 311

19.1 Quality Checks of Engineered Surface 311

19.1.1 Microstructure $\quad 312$

19.1.2 Composition 314

19.1.3 Hardness 315

19.1.4 Surface Roughness 317

19.1.5 Performance Tests 318

19.2 Surface Modification Processes and Surface Qualities 319

19.2.1 Diffusion Control Processes 319

19.2.2 Vapor Phase Deposition 320

19.2.3 Ion Implanted Surfaces 323

19.2.4 Thermal Spraying 324

19.2.5 Welding 326

References 328

CHAPTER 20

PROGNOSTIC AND LIFE CYCLE EXTENSION 331

20.1 Prognostic 331

Fracture Toughness \& Life Cycle 334 
$\begin{array}{ll}\text { Fatigue Life } & 339\end{array}$

Creep Life $\quad 342$

Wear Life in Different Wear Processes 344

Adhesive Wear Life $\quad 345$

Abrasive Wear Life $\quad 346$

Erosive Wear Life $\quad 347$

Thermal Wear $\quad 350$

Zero Wear or (IBM) Equation $\quad 351$

Corrosion Wear Life $\quad 352$

Corrosion Life using Fracture Mechanics 352

Wear Life from Long Time Wear Simulation Tests 354

On-line Wear Health Monitoring $\quad 355$

Thin Layer Activation $\quad 356$

Acoustic Emission $\quad 356$

References $\quad 356$

$\begin{array}{ll}\text { Subject Index } & 359\end{array}$

$\begin{array}{ll}\text { About Author } & 375\end{array}$ 


\section{PREFACE}

Surfaces are the bounding faces of solids. The interaction of component surface with the working environment results in wear \& corrosion. Estimated loss due to wear \& corrosion in USA is around $\$ 500$ billion. Engineered surfaces are the key to the reduction of losses due to wear and corrosion. In the USA, around 9524 establishments (including automotive, aircraft, power and construction industries) depend on engineered surfaces with support from 23,466 industries. Around 65 top academic institutions world-wide are engaged in surface engineering research and teaching.

There has been a paradigm shift in surface engineering from age-old electroplating to processes such as vapor phase deposition, diffusion, thermal spray \& welding using advanced heat sources like plasma, laser, ion, electron, microwave, solar beams, pulsed arc, pulsed combustion, spark, friction and induction. Metal, ceramic, polymer and composite surfaces are modified by application of heat or thermally assisted coatings with dissimilar materials. In addition to conventional materials it is possible to develop newer coating materials by processes such as RSP (metallic glasses), plasma polymerization (polymers and copolymers) and thermal spray (graded deposits). The application range includes critical components from almost all major industries, such as automotive, power, steel ,aerospace, nuclear, cement, petrochemical, chemical, construction, tools \& dies and biomedical equipments. Quality control of the engineered surface assures improved and consistent performance. A wear prognostic approach has been found useful to assess, monitor and improve the life of components in aging equipments and machineries. An attempt has been made to cover all these and few more topics in this book.

There are surface engineering books on specific processes such as thermal spraying and vapor phase deposition or about specific heat sources such as plasma or laser. However, there are few, if any, covering the whole range of advanced surface engineering processes. The manufacturing (OEM) and maintenance $(M \& R)$ of modern equipments and machineries, such as jet engines, require a number of advanced surface engineering processes for reliable, consistent and improved performance in the most hostile environment. It is imperative that those who are engaged in these and other related areas should be conversant with the newer competitive surface engineering processes. The present book has been structured to provide assistance $\&$ guidance to the engineers, researchers and students in choosing the right process from the galaxy of newer surface engineering techniques using advanced heat sources. 


\section{Acknowledgement}

I am grateful to my ex-colleague \& friend Prof. Joaquin LiraOlivares, Professor of Material Science, Centro de Ingenieria de Superficies, Universidad Simon Bolivar, Caracas, Venezuela, for making an excellent prepublication review. I appreciate the constructive pre-publication review made by Louis G. Hector, Jr., Ph.D, Research Scientist, R\&D and Planning, General Motors MC, USA. I am thankful to Dr. James B. Adams, Professor, Chemical and Materials Engineering, Arizona State University Tempe, AZ, for helping me in the review process.

I would like to thank the following accomplished technologists for their help \& support in this project:- Dr. C.K. Gupta, ex-Director, Materials Group, Dr. M.K. Totlani, ex-Head, Surface Engineering, and G.L. Goswami, Laser Processing \& Advance Welding, of Bhabha Atomic Research Center, Mumbai, India.

Dr. A.K. Nath, Head, Laser Programme, Center for Advance Technology, Indore, India; Dr. P.I. John, Institute of Plasma Research, Gandhinagar, India. Dr. K. Shridhar, Naval Materials Research Laboratories, Mumbai.

Thanks to Gregory T. Franklin, Carol Day and all other staff members of Kluwer Academic Publishers who have done commendable work in publishing the book in the shortest possible time frame. Thanks to Ms. Poonam for her help in making the camera ready copy of the book.

My elder son Romik (University of Texas at Austin) \& his wife Robin and younger son Raunak (Motorola, Texas) have given me unfailing support all through the project. Thanks to all of them. Thanks to Chiraranjan for providing assistance especially in designing the cover page.

My wife Mandira (Vice Principal \& Reader), despite her extremely busy schedule has devoted considerable time in correcting and sequencing the manuscript in its final form. I shall be failing in my duties if I do not acknowledge her generous support and help in this mission. 